\title{
For Whom the Sirens Toll: A Study on an Ethical Challenge in Prehospital Emergency Medicine
}

\author{
Hasan Erbay' (D, Rana Can² (D), Ayca Hatice Turkan³ (D) \\ 'Department of History of Medicine and Ethics, Afyon Kocatepe University School of Medicine, Afyonkarahisar, Turkey \\ ${ }^{2}$ Department of Nursing, Mustafa Kemal University Hatay School of Medicine, Hatay, Turkey \\ ${ }^{3}$ Department of Statistics, Afyon Kocatepe University School of Science and Literature, Afyonkarahisar, Turkey
}

Cite this article as: Erbay H, Can R, Turkan AH. For Whom the Sirens Toll: A Study on an Ethical Challenge in Prehospital Emergency Medicine. Eurasian J Emerg Med. 2018; 17 (3): 122-8.

\begin{abstract}
Aim: The main responsibility of an emergency medical dispatcher (EMD) is to determine the situation and location of an emergency and allocate emergency resources to the scene. However, in some cases, there might be more than one emergency calls at one time forcing an EMD to decide which call should be given priority. Triage, prioritization, and choosing are issues that may be influenced by the EMD's personal values and thus raise ethical challenges. The aim of the present study was to determine (theoretically) the triage decisions of dispatchers in equal emergency care situations and the factors influencing their thinking and decisions.

Materials and Methods: A questionnaire containing two emergency scenarios was applied to 92 students who were candidate ambulance dispatchers in training. The distribution of the participants' response was analyzed and the Chi-square and Fisher's exact tests of independence were performed.

Results: Most of the participants chose to direct the ambulance to the orphanage. Results showed that the number of victims was the main factor influencing priorities and resource allocation in an emergency. In the second survey, age of the injured person influenced the choices.

Conclusion: In triage decisions, EMD students prioritize the age and the number of the victims while deciding the allocation of emergency resources. It includes many individual values that might influence the decision. The ethical conflict of principles in a triage decision is between justice and beneficence.
\end{abstract}

Keywords: Emergency dispatch center, ethics, triage, decision-making

\section{Introduction}

An emergency medical dispatcher (EMD) is a professional tele communicator who gathers information about medical emergencies, provides assistance through emergency medical advice and instruction, and dispatches emergency medical service (EMS) resources to the scene. Evidently, the types of tasks and resources that EMDs handle may change among countries (1). EMSs include the ambulance service as well as the fire and police department in some countries.
Regardless of the type of EMS, the main role of an EMD is to determine the situation and location and to dispatch the EMS resources to the emergency. However, in some cases, there might be more than one emergency calls at one instance, and an EMD needs to prioritize the calls. An EMD is the person who must establish priorities for the allocation of limited EMS resources. During an emergency, the process of organizing the closest appropriate ambulance to the person in genuine need is crucial. It is called (tele) phone triage and it involves many technical, medical, and ethical challenges.

ORCID IDs of the authors: H.E. 0000-0002-5436-3961; R.C. 000000030655 4736; A.H.T. 0000-0002-4375-9733. 
In Turkey, there are currently two types of emergency dispatch centers: one is just for medical emergency calls and the other is a combination of medical, fire, and police departments. The government's plan is to complete the combination process throughout the country by the end of 2016 (2). The emergency call number is 112 in Turkey, and the dispatchers answering the calls are healthcare professionals. In recent years, the dispatchers have developed to be more professional and have improved their communication skills through a special school for dispatcher education. The Turkish EMS system is based on the perspective of "scoop and run," which indicates to avoid time wasting at the scene by transporting the patient to the nearest convenient hospital and providing emergency care during transport (3).

It is a critical aspect of an EMD's responsibility to prioritize dispatch of service $(4,5)$. Although some electronic systems and programs are available, it is essential for EMDs to prioritize the calls (6). Performing triage of incoming calls is one of the responsibilities of the EMD. Triage, prioritization, and decision-making are issues that might be influenced by personal values and thus are worth consideration (7).

Decisions on how to distribute the EMSs among multiple patients raise important ethical issues of distributive justice (8). These preferences are not mere medical judgments because they are strongly influenced by the decision makers' characters, perceptions, and values.

\section{Triage}

Triage is a French term indicating to "choose" and "sort." It is mostly practiced by prehospital emergency care givers in their daily routines, which means doing "the greatest good for the greatest number" by classifying patients $(9,10)$.

There are three stages of triage in the modern healthcare systems $(11,12)$ :

- $\quad$ Prehospital triage to dispatch prehospital care resources (EMS);

- $\quad$ Triage at the scene by the first emergency healthcare providers attending to the patient(s);

- Triage upon arrival at the hospital emergency department.

(Tele) phone triage is used for primary ambulance triage, which is the issue studied in this article, and is different from the on-scene triage. It is a dynamic task and needs a significant level of practice, skill, and medical maturity. No EMD can realistically consider all the compounding variables for every decision, which questions the practice of phone triage (13). The crucial question is "How can an EMD be objective and fair during triage"?

While seeking to obtain the most utility from the resources, ethical challenges arise in terms of deciding the best way to allocate the limited resources $(14,15)$. It is the duty of justice, which states "equals should be treated equally and unequals unequally in proportion to the relevant inequalities" by the principle of formal "distributive justice" (9). In emergency medical practice, the most direct application of distributive justice is in triage (16). The principle that an EMD holds as a core value is the idea that patients will be served according to their medical need. Some issues, such as social status and economic condition, should not limit access to emergency care (17).

\section{Objective}

The aim of the current study was to determine (theoretically) EMDs' decisions in equal emergency care situations via phone triage and the factors that influence their decisions.

\section{Research Design}

\section{Data collection}

A questionnaire was used to collect data. Face-to-face interviews of participants were conducted. The questionnaire consisted of two parts. The first part contained demographic information about the participants, such as class, gender, and age. The second part contained two emergency scenarios to measure participants' attitudes.

\section{SCENARIO 1}

You are a dispatcher in a small city's emergency dispatch centre that directs all EMS (Emergency Medical Service) ambulances and fire departments. There is only one ambulance and fire crew available for any operation at a time. During your shift, fire alarm tolls at three different buildings far from each other almost at the same time. One building is an orphanage, and the others are an eventide home and a prison.

1. Based on the scenario and available resources, what location do you direct the only ambulance to? (please select one option)
a) The orphanage
b) The eventide home
c) The prison

2. Based on the scenario, where do you send the only fire crew? (please select one option)
a) The orphanage
b) The eventide home
c) The prison

3. Independent from the case above; when sending an ambulance to an emergency situation, what is the main factor influencing your decision? (please make one selection)

a) The age of the victims

b) The number of the victims

c) The dependency of someone else care of the victims

d) The gender of the victims

e) The social position of the victims

\section{SCENARIO 2}

You are a member of the ambulance crew that is transporting a patient who is (medically) stable and conscious to another city. During the transport, you come across a recent traffic accident. You observe the accident and notice there are three people injured. You can only take one of the injured, in addition to your patient currently in transfer. You notice that all three injured from the car accident suffer from identical injuries.

One of these three is a child aged 6-7, while the others are a woman in her thirties and a man in his seventies.

4. Based on the scenario, which injured person do you transport to the hospital? (please click one selection)
a) The child
b) The woman
c) The man 
5. What is the factor that led to your decision? (please click one selection)

a) The age of the injured one

b) The gender of the injured one

6. Would you prefer to change your earlier decision if any of the injured people or their close family and friends is strong in terms of social-political-administrative or academics etc.? (Please choose one.)

(Would it have changed your choice if any of the injured people or their closest person had been strong in terms of social-political-administrative or academic etc.?) (Please click one selection.)

a) Yes, I would have changed my decision

b) I am not sure

c) No, I would not have changed my decision

7. You have learned that the injured women in her thirties is pregnant. In that case, which injured person would you get the transport to hospital? (please click one selection)

a) The child

b) The woman

c) The man

\section{Methods}

The questionnaire was applied to 92 students who were candidate ambulance dispatchers attending the Mustafa Kemal University Department of Emergency and Disaster Management for May-June 2015. The sample consisted of 108 students, some of whom were on duty in a few healthcare services. Initially, the questionnaire was tested among eight people as a pilot study. Based on their comments, it was adjusted and applied in the present study.

Approval was obtained from the Afyonkarahisar Clinical Trials Ethics Committee (05.03.2015/2015/04-121), and participants were assured that their participation was voluntary.

\section{Statistical analysis}

Data analysis was performed using the R program. First, the distribution of the participants was analyzed. In the second section, the Chi-square test of independence and Fisher's exact test of independence were per- formed to determine whether there were associations between demographic characteristics and responses to the scenario questions. In this context, each null hypothesis can be expressed as follows:

Null hypothesis: The response is not influenced by personal characteristics.

Before performing the tests of independence, data were organized in a contingency table and the expected counts were calculated. If any expected count was very low $(<5)$, the Chi-square test of independence was deemed inappropriate and Fisher's Exact test of independence was used instead.

If a $p$ value is less than the significance level (), the null hypothesis of the independence assumption is rejected.

\section{Results}

According to the results obtained from the data analyses, 45 (48.9\%) participants were first-year students, 64 (69.6\%) were males, 33

Table 1. Demographic characteristics of participants

\begin{tabular}{|l|c|c|c|}
\hline Variables & Groups & Frequencies & $\%$ \\
\hline \multirow{4}{*}{ Class } & 1 & 45 & 48.9 \\
\cline { 2 - 4 } & 2 & 27 & 29.3 \\
\hline \multirow{3}{*}{ Gender } & Female & 28 & 21.7 \\
\cline { 2 - 4 } & Male & 64 & 30.4 \\
\hline \multirow{3}{*}{ Age, years } & $<20$ & 30 & 69.6 \\
\cline { 2 - 4 } & 20 & 29 & 32.6 \\
\cline { 2 - 4 } & $>20$ & 33 & 31.5 \\
\hline \multirow{3}{*}{ Working status } & Employed & 20 & 21.7 \\
\cline { 2 - 4 } & Unemployed & 72 & 78.3 \\
\hline Child & Yes & 0 & 0.0 \\
\cline { 2 - 4 } & No & 92 & 100.0 \\
\hline Total & & 92 & 100.0 \\
\hline
\end{tabular}

Table 2. Distribution of the responses for the question "What location do you direct the only ambulance to?"

\begin{tabular}{|c|c|c|c|c|c|c|}
\hline & & Orphanage & Eventide home & Prison & Total & $\mathbf{p}$ \\
\hline \multirow[t]{3}{*}{ Class } & 1 & 40 (88.9\%) & $2(4.4 \%)$ & $3(6.7 \%)$ & 45 & \multirow[t]{3}{*}{0.646} \\
\hline & 2 & 25 (92.6\%) & $0(0.0 \%)$ & $2(7.4 \%)$ & 27 & \\
\hline & 3 & 17 (85.0\%) & $2(10.0 \%)$ & $1(5.0 \%)$ & 20 & \\
\hline \multirow[t]{2}{*}{ Gender } & Female & $25(89.3 \%)$ & $2(7.1 \%)$ & $1(3.6 \%)$ & 28 & \multirow[t]{2}{*}{0.644} \\
\hline & Male & 57 (89.1\%) & $2(3.1 \%)$ & $5(7.8 \%)$ & 64 & \\
\hline \multirow{2}{*}{ Age, years } & 20 & 28 (96.6\%) & $0(0.0 \%)$ & $1(3.4 \%)$ & 29 & \multirow{2}{*}{0.466} \\
\hline & $>20$ & $28(84.8 \%)$ & $3(9.1 \%)$ & $2(6.1 \%)$ & 33 & \\
\hline \multirow[t]{2}{*}{ Working status } & Employed & 19 (95.0\%) & $1(5.0 \%)$ & $0(0.0 \%)$ & 20 & \multirow[t]{2}{*}{0.469} \\
\hline & Unemployed & $63(87.5 \%)$ & $3(4.2 \%)$ & $6(8.3 \%)$ & 72 & \\
\hline
\end{tabular}


Table 3. Distribution of the responses for the question "Where do you send the only fire crew?"

\begin{tabular}{|c|c|c|c|c|c|c|}
\hline & & Orphanage & Eventide home & Prison & Total & $\mathbf{p}$ \\
\hline \multirow[t]{2}{*}{ Class } & 1 & $35(77.8 \%)$ & $2(4.4 \%)$ & $8(17.8 \%)$ & 45 & \multirow[t]{2}{*}{0.373} \\
\hline & 2 & $23(85.2 \%)$ & $3(11.1 \%)$ & $1(3.7 \%)$ & 27 & \\
\hline \multirow[t]{2}{*}{ Gender } & Female & $21(75.0 \%)$ & $2(7.1 \%)$ & $5(17.9 \%)$ & 28 & \multirow[t]{2}{*}{0.478} \\
\hline & Male & $53(82.8 \%)$ & $5(7.8 \%)$ & $6(9.4 \%)$ & 64 & \\
\hline \multirow{2}{*}{ Age, years } & 20 & $25(86.2 \%)$ & $2(6.9 \%)$ & $2(6.9 \%)$ & 29 & \multirow{2}{*}{0.515} \\
\hline & $>20$ & $28(84.8 \%)$ & $2(6.1 \%)$ & $3(9.1 \%)$ & 33 & \\
\hline \multirow[t]{2}{*}{ Working status } & Employed & $18(90.0 \%)$ & $0(0.0 \%)$ & $2(10.0 \%)$ & 20 & \multirow[t]{2}{*}{0.451} \\
\hline & Unemployed & $56(77.8 \%)$ & $7(9.7 \%)$ & $9(12.5 \%)$ & 72 & \\
\hline
\end{tabular}

Table 4. Distribution of the responses for the question "Independent from the case; when sending an ambulance to an emergency situation, what is the main factor influencing your decision?"

\begin{tabular}{|c|c|c|c|c|c|c|c|}
\hline & & $\begin{array}{l}\text { Age of the } \\
\text { victims }\end{array}$ & $\begin{array}{l}\text { Number of } \\
\text { the victims }\end{array}$ & $\begin{array}{l}\text { Dependency of } \\
\text { someone else } \\
\text { care of victims }\end{array}$ & $\begin{array}{l}\text { Social position } \\
\text { of the victims }\end{array}$ & Total & $\mathbf{p}$ \\
\hline \multirow[t]{3}{*}{ Class } & 1 & $9(20.0 \%)$ & 19 (42.2\%) & 7 (15.6\%) & $10(22.2 \%)$ & 45 & \multirow[t]{3}{*}{$0.029 *$} \\
\hline & 2 & $9(33.3 \%)$ & 14 (51.9\%) & $4(14.8 \%)$ & $0(0.0 \%)$ & 27 & \\
\hline & 3 & $4(20.0 \%)$ & $6(30.0 \%)$ & $8(40.0 \%)$ & $2(10.0 \%)$ & 20 & \\
\hline Gender & Male & 17 (26.6\%) & 31 (48.4\%) & $8(12.5 \%)$ & $8(12.5 \%)$ & 64 & $0.031^{*}$ \\
\hline \multirow[t]{3}{*}{ Age, years } & $<20$ & $6(20 \%)$ & $14(46.7 \%)$ & $4(13.3 \%)$ & $6(20 \%)$ & 30 & \multirow[t]{3}{*}{0.369} \\
\hline & 20 & $8(27.6 \%)$ & 14 (48.3\%) & $4(13.8 \%)$ & $3(10.3 \%)$ & 29 & \\
\hline & $>20$ & $8(24.2 \%)$ & 11 (33.3\%) & $11(33.3 \%)$ & $3(9.1 \%)$ & 33 & \\
\hline
\end{tabular}

${ }^{*} p<0.05$

Table 5. Distribution of the responses for the question "Which injured person do you transport to the hospital?"

\begin{tabular}{|c|c|c|c|c|c|c|}
\hline & & Orphanage & Eventide home & Prison & Total & $\mathbf{p}$ \\
\hline \multirow[t]{3}{*}{ Class } & 1 & 40 (88.9\%) & $3(6.7 \%)$ & $2(4.4 \%)$ & 45 & \multirow[t]{3}{*}{0.547} \\
\hline & 2 & 24 (88.9\%) & $3(11.1 \%)$ & $0(0.0 \%)$ & 27 & \\
\hline & 3 & 17 (85.0\%) & $1(5.0 \%)$ & $2(10.0 \%)$ & 20 & \\
\hline \multirow[t]{2}{*}{ Gender } & Female & $25(89.3 \%)$ & $2(7.1 \%)$ & $1(3.6 \%)$ & 28 & \multirow[t]{2}{*}{1.000} \\
\hline & Male & $56(87.5 \%)$ & $5(7.8 \%)$ & $3(4.7 \%)$ & 64 & \\
\hline \multirow[t]{3}{*}{ Age, years } & $<20$ & $25(83.3 \%)$ & $3(10.0 \%)$ & $2(6.7 \%)$ & 30 & \multirow[t]{3}{*}{0.699} \\
\hline & 20 & 27 (93.1\%) & 2 (6.9\%) & $0(0.0 \%)$ & 29 & \\
\hline & $>20$ & $29(87.9 \%)$ & $2(6.1 \%)$ & $2(6.1 \%)$ & 33 & \\
\hline \multirow[t]{2}{*}{ Working status } & Employed & 18 (90.0\%) & $2(10.0 \%)$ & $0(0.0 \%)$ & 20 & \multirow[t]{2}{*}{0.591} \\
\hline & Unemployed & $63(87.5 \%)$ & $5(6.9 \%)$ & $4(5.6 \%)$ & 72 & \\
\hline
\end{tabular}


(35.9\%) were older than 20 years, 72 (78.3\%) were not employed, and none of the participants had a child (Table 1).

Most participants chose directing the ambulance to the orphanage (Table 2).

Most participants chose directing the fire crew to the orphanage (Table 3). Prison was the second choice.

Results of the third question indicate that the number of victims was the greatest factor influencing the emergency resource allocation (Table 4). The first-year students' second choice was social position of the victims, and the third-year students' first choice was the dependency of someone else to care for the victims.

In the second scenario, most participants specified that they would first transport the injured child to the hospital (Table 5).

Age of the injured victim led the students to choose the child (Table 6).

The participants mostly stated that they would not change their earlier decision if any of the injured victim or their spouses were strong in terms of social-political-administrative or academic positions, etc., (Table 7).
The decision of the students after learning that the injured woman was pregnant was mostly to get her to the ambulance and take her to hospital (Table 8). None of the participants chose the man.

According to the $p$ values, we can conclude that the responses for the third question of scenario 1 were influenced by class $(p=0.029<a=0.05)$ and gender $(p=0.031<\alpha=0.05)$ of the participants. Other responses do not seem to be related to class or gender. Additionally, the responses to each scenario are independent of age and working status of the participants.

\section{Discussion}

It is important in emergency medicine to ensure equal availability, justice, and fairness of emergency medical care (18-20). This indicates treating the patient in an unbiased and unprejudiced manner regardless of their status or position $(15,17,21)$. However, in disasters, where there is an acute and unforeseen imbalance between the capacity and resources of the medical profession and the needs of survivors, EMS organizations and crews face ethical challenges while deciding the best way to allocate resources $(10,13,22-24)$. The resources of any EMS system are finite and the crew is under the pressure of the limited time during these kinds of triage decisions (4).

Table 6. Distribution of the responses for the question "What is the factor that led to your decision?"

\begin{tabular}{|c|c|c|c|c|c|}
\hline & & $\begin{array}{l}\text { Age of the } \\
\text { injured one }\end{array}$ & $\begin{array}{l}\text { Gender of the } \\
\text { injured one }\end{array}$ & Total & $\mathbf{p}$ \\
\hline \multirow[t]{2}{*}{ Class } & 1 & 45 (100.0\%) & $0(0.0 \%)$ & 45 & \multirow[t]{2}{*}{0.511} \\
\hline & 3 & $20(100.0 \%)$ & $0(0.0 \%)$ & 20 & \\
\hline Gender & Female & $28(100.0 \%)$ & $0(0.0 \%)$ & 28 & 1.000 \\
\hline \multirow[t]{3}{*}{ Age, years } & $<20$ & 30 (100.0\%) & $0(0.0 \%)$ & 30 & \multirow[t]{3}{*}{0.315} \\
\hline & 20 & $28(96.6 \%)$ & $1(3.4 \%)$ & 29 & \\
\hline & $>20$ & $33(100.0 \%)$ & $0(0.0 \%)$ & 33 & \\
\hline Working status & Employed & 20 (100.0\%) & $0(0.0 \%)$ & 20 & 1.000 \\
\hline
\end{tabular}

Table 7. Distribution of the responses for the question "Would you prefer to change your earlier decision if any of the injured people or their close family and friends is strong in terms of social-political-administrative or academics etc.?"

\begin{tabular}{|c|c|c|c|c|c|c|}
\hline & & $\begin{array}{c}\text { Would change } \\
\text { decision }\end{array}$ & Not sure & $\begin{array}{c}\text { Would not change } \\
\text { decision }\end{array}$ & Total & $\mathbf{p}$ \\
\hline \multirow[t]{3}{*}{ Class } & 1 & $1(2.2 \%)$ & $3(6.7 \%)$ & 41 (91.1\%) & 45 & \multirow[t]{3}{*}{0.708} \\
\hline & 2 & 1 (3.7\%) & $2(7.4 \%)$ & 24 (88.9\%) & 27 & \\
\hline & 3 & $1(5.0 \%)$ & $3(15.0 \%)$ & 16 (80.0\%) & 20 & \\
\hline \multirow[t]{2}{*}{ Gender } & Female & $1(3.6 \%)$ & $1(3.6 \%)$ & 26 (92.9\%) & 28 & \multirow[t]{2}{*}{0.552} \\
\hline & Male & $2(3.1 \%)$ & $7(10.9 \%)$ & 55 (85.9\%) & 64 & \\
\hline \multirow[t]{3}{*}{ Age, years } & $<20$ & $1(3.3 \%)$ & $3(10.0 \%)$ & 26 (86.7\%) & 30 & \multirow[t]{3}{*}{0.956} \\
\hline & 20 & $1(3.4 \%)$ & $3(10.3 \%)$ & 25 (86.2\%) & 29 & \\
\hline & $>20$ & 1 (3.0\%) & $2(6.1 \%)$ & 30 (90.9\%) & 33 & \\
\hline \multirow[t]{2}{*}{ Working status } & Employed & $0(0.0 \%)$ & $2(10.0 \%)$ & 18 (90.0\%) & 20 & \multirow[t]{2}{*}{1.000} \\
\hline & Unemployed & $3(4.2 \%)$ & $6(8.3 \%)$ & $63(87.5 \%)$ & 72 & \\
\hline
\end{tabular}


Table 8. Distribution of the responses for the question "You have learned that the injured women in her thirties is pregnant. In that case, which injured person would you get the transport to hospital?"

\begin{tabular}{|c|c|c|c|c|c|}
\hline & & Child & Woman & Total & $\mathbf{p}$ \\
\hline \multirow[t]{2}{*}{ Class } & 1 & $3(6.7 \%)$ & 42 (93.3\%) & 45 & \multirow[t]{2}{*}{1.000} \\
\hline & 2 & $2(7.4 \%)$ & 25 (92.6\%) & 27 & \\
\hline \multirow[t]{2}{*}{ Gender } & Female & $2(7.1 \%)$ & 26 (92.9\%) & 28 & \multirow[t]{2}{*}{1.000} \\
\hline & Male & $4(6.3 \%)$ & 60 (93.8\%) & 64 & \\
\hline \multirow{2}{*}{ Age, years } & 20 & $3(10.3 \%)$ & 26 (89.7\%) & 29 & \multirow{2}{*}{0.435} \\
\hline & $>20$ & $1(3.0 \%)$ & 32 (97.0\%) & 33 & \\
\hline \multirow[t]{2}{*}{ Working status } & Employed & $0(0.0 \%)$ & 20 (100.0\%) & 20 & \multirow[t]{2}{*}{0.333} \\
\hline & Unemployed & $6(8.3 \%)$ & 66 (91.7\%) & 72 & \\
\hline
\end{tabular}

The conflicts that EMDs experience in triage decisions are different from those they experience at the scene. From an EMD's perspective, in addition to the potential problems and misunderstandings in communication, decision-making in mass casualty care is also a challenge. EMDs face ethical challenges when deciding on the best way to allocate resources (which mostly means ambulances). Obviously, their decisions to choose someone during these situations may be different from those in daily routines. The conflict of ethical principles in such cases is between the principles of duty and utility (14).

In some studies, it has been stated that the healthcare providers acted according to how they would want to be treated in a similar situation (25). In triage decisions, this inevitably resulted in the way of individual choices (biased choices). In fact, professionalism means acting neutrally toward people, but this is clearly difficult in such challenging circumstances. As found in the present study, responders prioritize children first. It is probably related to the expected lifetime of the victims. In routine daily life, many people hope for a child to live longer than an adult or elderly. In a highly stressed and ethically sensitive environment, this preference may dominate and influence the decision in favor of children.

Interestingly, there was no significant difference on directing an ambulance to the orphanage in the subgroups and the social position of the victims. Directing the fire crew to the cases is a bit different from directing the ambulance. It is probably the effect of the bars of the prison and the need for professional support to pull the prisoners out that influences this choice.

The fundamental equality of all individuals is an important perspective that should not be influenced particularly by any social status of the people. In this study, participants mostly stated that they would not change their earlier decision if any of the injured ones or their spouses were strong in terms of social-political-administrative or academic positions. This is an important point that their perspective on the equality of all humans will continue when they really become in charge in future.

Two of the ethical principles most pertinent to this discussion are justice and beneficence. In this regard, justice is principally considered distributive justice, which is based on the core principle that everyone should receive the amount of goods he or she merited within a community (26). Moreover, it is a subgroup of distributive justice, prioritization, that plays a crucial role in prehospital emergency (tele)phone triage (27). An EMD who has a challenging situation strives to achieve a balance of two principles: the principles of duty and utility. An EMD must make a choice about "who shall live when not everyone can live?" It most undoubtedly affects the ethical values of the EMD and his or her individual preferences (7). At this stage, it is not merely a related issue about adherence to ethical principles. It is an individual choice about expectancy of life (time), innocent ones, dependency of someone else, deprived of liberty, and or show mercy to those most vulnerable.

Subsequently, beneficence is the other primary concern during triage; however, it is also relative to the situation. What is the main purpose-saving most victims or rescuing only one person who is really in need of an ambulance for further emergency care? Disaster triage decisions are intrinsically utilitarian, making an effort to do the most for the most (which means the number), with the limited resources (11). This is an important point of attitude that creates a great challenge in the EMD's mind (4). The age of the victims also generates a challenge for EMDs. Age, the second most prioritized parameter, might influence EMDs in that younger people deserve the ambulance more than elders do. Obviously, this stigmatization should not affect the healthcare providers.

Based on the results, it was concluded that most participants in this study chose the orphanage. There was no difference in subgroups; however, in scenario 1-question 3, there were some differences in terms of class and gender of the participants. The provision of ethics education explains the differences between classes. An interdisciplinary format on disaster medicine and triage education, including dispatching, medical assistance, law, coordination, communication, and ethics, can make a difference on students' triage decisions (28). At the school in which this study was conducted, ethics education begins mainly in the second grade. Hence, it could be seen that the impact of the social status of the injured one does not influence the decision of the EMD. Another difference may be a diversion of perception about care and differences of women, who are more important to them in the decision-making process (29).

As "triage" is fundamentally a military term, prioritization of wounded soldiers is based on a utilitarian approach that considers a significant number (13). In this study, the pregnant woman was preferred by the participants over the number of victims. Moreover, it might be the age as a factor of preference. Contemplating these scenarios may generate differences; however, it is possible that healthcare providers play it by the ear when deciding according to the manner in which a situation develops. 
There are different prehospital and emergency service guidelines for triage in international literature, including triage score, acuity score, triage scale, and severity index (24, 30-32). The algorithm Simple Triage and Rapid Transport (START) is mainly used in emergency medicine in Turkey. Obviously, the principle of utility is not the only ethical approach for triage. Doing the greatest good for the greatest number, by means of utilitarianism, might be considered the rationale for triage systems. However, it is important for the EMS personnel to approach triage and related issues from a wider perspective. The number of survivors is important but it is not the only factor to consider.

Finally, it should be noted that triage involves significant moral implications. Therefore, it requires effective ethics education for the EMSs and re-thinking on triage by means of the term, ethical features, and decision-making process. Triage is conceptually very clear but practically and ethically very complicated (13).

\section{Study limitations}

The study was based on two theoretical scenarios, which is a limitation. They were unusual triage scenarios for EMDs. Furthermore, all participants were students and they were not legitimate EMDs. However, this does not prevent us from evaluating the issue of ethical aspects of triage decisions.

\section{Conclusion}

In triage decisions, EMD students prioritize the age and the number of victims. Triage decisions include many individual characteristics that might affect the current decision. There was no difference with regard to gender, but it could mean the over triage of some victims based on age and number.

The ethical conflicts of principles in triage decision-making are justice and beneficence. Although there are many strategies for triage, highlighting the number victims is the most common approach. However, it may be ethically risky to handle the victims by number. The injured victims should not be treated as numbers only because each individual has a value that cannot be measured merely in terms of numbers or age. Triage is a matter that comprises not only medical issues but also ethical, public health, political, and planning of health resource issues.

Ethics Committee Approval: Ethics committee approval was received for this study from the Ethics Committee of Afyonkarahisar Clinical Trials Ethics Committee (05.03.2015/ 2015/04-121).

Informed Consent: Written informed consent that on the first part of questionnaire was obtained from participants, who participated in this survey.

Peer-review: Externally peer-reviewed.

Author Contributions: Concept - H.E.; Design - H.E.; Supervision - R.C., A.H.T.; Resources - H.E., R.C.; Materials - H.E., R.C.; Data Collection and/or Processing R.C.; Analysis and/or Interpretation - A.H.T.; Literature Search - H.E., R.C., A.H.T.; Writing Manuscript - H.E., A.H.T.; Critical Review - R.C., A.H.T.

Conflict of Interest: The authors have no conflict of interest to declare.

Financial Disclosure: The authors declared that this study has received no financial support.

\section{References}

1. Huibers L, Smits M, Renaud V, Giesen P, Wensing M. Safety of telephone triage in out-of-hours care: a systematic review. Scand J Prim Health Care. 2011; 29: 198-209. [CrossRef]
2. Icisleri Bakanligi. 112 acil cagri merkezleri kuruluş, görev ve calisma yonetmeligi. 2014; 1-26

3. Smith RM, Conn AK. Prehospital care - Scoop and run or stay and play? Injury. 2009; 40: 23-6. [CrossRef]

4. Erbay, H. Some ethical issues in prehospital emergency medicine. Turk J Emerg Med. 2014; 14: 193-8. [CrossRef]

5. Adams JG, Arnold R, Siminoff L, Wolfson AB. Ethical conflicts in the prehospital setting. Ann Emerg Med. 1992; 21: 1259-65. [CrossRef]

6. Benson $\mathrm{M}$, Koenig $\mathrm{KL}$, Schultz $\mathrm{CH}$. Disaster triage: START, then SAVE--a new method of dynamic triage for victims of a catastrophic earthquake. Prehosp Disaster Med. 1996; 11: 117-24. [CrossRef]

7. Ellensen EN, Hunskaar S, Wisborg T, Zakariassen E. Variations in contact patterns and dispatch guideline adherence between Norwegian emergency medical communication centres - a cross-sectional study. Scand J Trauma Resusc Emerg Med. 2014; 22: 2. [CrossRef]

8. Geiderman JM, Marco CA, Moskop JC, Adams J, Derse AR. Ethics of ambulance diversion. Am J Emerg Med. 2014; 33: 1-6.

9. Ersoy N, Akpınar A. Triage decisions of emergency physicians in Kocaeli and the principle of justice. Turkish J Trauma Emerg Surg. 2010; 16: 203-9.

10. Funderburke P. Exploring best practice for triage. J Emerg Nurs. 2008; 34: 180-2. [CrossRef]

11. Sztajnkrycer MD, Madsen BE, Alejandro Baez A. Unstable Ethical Plateaus and Disaster Triage. Emerg Med Clin North Am. 2006; 24: 749-68. [CrossRef]

12. Robertson-Steel I. Evolution of triage systems. Emerg Med J. 2006; 23: 154-5. [CrossRef]

13. Repine TB, Lisagor P, Cohen DJ. The Dynamics and Ethics of Triage: Rationing Care in Hard Times. Mil Med. 2005; 170: 505-9. [CrossRef]

14. BeckerTK, Gausche-Hill M, Aswegan AL, Baker EF, Bookman KJ, Bradley RN, et al. Ethical challenges in Emergency Medical Services: controversies and recommendations. Prehosp Disaster Med. 2013; 28: 488-97. [CrossRef]

15. Larkin GL, Fowler RL. Essential ethics for EMS: cardinal virtues and core principles. Emerg Med Clin North Am. 2002; 20: 887-911. [CrossRef]

16. Iserson KV. Ethical principles--emergency medicine. Emerg Med Clin North Am. 2006; 24: 513-45. [CrossRef]

17. James A, Terri S, Art SL, La G, Robert K. Professionalism in Emergency Medicine. Acad Emerg Med. 1998; 5: 1193-9. [CrossRef]

18. ten Have HAMJ, Jean MS, editors. The UNESCO Universal Declaration on Bioethics and Human Rights Background, principles and application. France: UNESCO Publishing; 2009.p.173-85.

19. American College of Emergency Physicians. Code of Ethics for Emergency Physicians. Ann Emerg Med. 2017; 70: e17-25. [CrossRef]

20. National Association of Emergency Medical Technicians. Code of Ethics for EMS Practitioners.1978. Available from: URL: https://www.naemt.org/ about-ems/emt-oath.

21. World Medical Association. WMA Declaration of Geneva. 2006. Available from: URL: https://www.wma.net/policies-post/wma-declaration-of-geneva/

22. Domres B, Kees T, Gromer S, Braitmaier P, Tanja G. Ethical aspects of triage. Rocnik. 2010; 2: 76-82.

23. Moskop JC, Iserson KV. Triage in medicine, part II: Underlying values and principles. Ann Emerg Med. 2007; 49: 282-7. [CrossRef]

24. Aacharya RP, Gastmans C, Denier Y. Emergency department triage: an ethical analysis. BMC Emerg Med. 2011; 11: 16-25. [CrossRef]

25. Gunnarsson BM, Warrén Stomberg M. Factors influencing decision making among ambulance nurses in emergency care situations. Int Emerg Nurs. 2009; 17: 83-9. [CrossRef]

26. Bauzon S. Classical distributive justice and the European healthcare system: rethinking the foundations of European health care in an age of crises. J Med Philos. 2015; 40: 190-200. [CrossRef]

27. Dunlop M, Savulescu J. Distributive justice and cognitive enhancement in lower, normal intelligence. Monash Bioeth Rev. 2015; 32: 189-204. [CrossRef]

28. Pfenninger EG, Domres BD, Stahl W, Bauer A, Houser CM, Himmelseher S. Medical student disaster medicine education: the development of an educational resource. Int J Emerg Med. 2010; 3: 9-20. [CrossRef]

29. Sanz ML, Lizárraga DA, Sanz MT, Baquedano DA. Factors that affect decision making: gender and age differences. Int J Psychol Psychol Ther. 2007; 7:381-91.

30. Roudsari BS, Nathens AB, Cameron P, Civil I, Gruen RL, Koepsell TD, et al. International comparison of prehospital trauma care systems. Injury. 2007; 38: 993-1000. [CrossRef]

31. Risavi BL, Salen PN, Heller MB, Arcona S. A Two-Hour Intervention Using START Improves Prehospital Triage of Mass Casualty Incidents. Prehospital Emerg Care. 2001; 5: 197-9. [CrossRef]

32. Chen $\mathrm{K}$, Chen C, Wang T. The Role Tabletop Exercise Using START in Improving Triage Ability in Disaster Medical Assistance Team. Ann Disaster Med. 2003; 1: 78-84. 